MT-DP - 2015/11

\title{
Lying generators: Manipulability of centralized payoff mechanisms in electrical energy trade
}

\author{
DÁVID CSERCSIK
}




\title{
Discussion papers
}

MT-DP - 2015/11

Institute of Economics, Centre for Economic and Regional Studies, Hungarian Academy of Sciences

KTI/IE Discussion Papers are circulated to promote discussion and provoque comments. Any references to discussion papers should clearly state that the paper is preliminary. Materials published in this series may subject to further publication.

Lying generators: Manipulability of centralized payoff mechanisms in electrical energy trade

\author{
Author: \\ Dávid Csercsik \\ research fellow \\ Momentum Game Theory Research Group \\ Institute of Economics - Centre for Economic and Regional Studies \\ Hungarian Academy of Sciences \\ and \\ Pázmány Péter Catholic University \\ e-mail: csercsik.david@krtk.mta.hu
}

February 2015

ISBN $978-615-5447-70-9$

ISSN $1785377 \mathrm{X}$ 


\title{
Lying generators: Manipulability of centralized payoff mechanisms in electrical energy trade
}

\section{Dávid Csercsik}

\begin{abstract}
Optimal power flow (OPF) problems are focussing on the question how a power transmission network can be operated in the most economic way. The general aim in such scenarios is to optimize generator scheduling in order to meet consumption re-quirements, transmission constraints and to minimize the overall generation cost and transmission losses. We use a simple lossless DC load flow model for the description of the transmission network, and assume linearly decreasing marginal cost of generators with different parameters for each generator. We consider a scenario in which the generation values regarding the OPF are calculated by a central authority who is aware of the network parameters and production characteristics. Furthermore, we assume that a central mechanism is applied for the determination of generator payoffs in order to cover their generation costs and assign them with some profit. We analyze the situation when generators may provide false information about their production parameters and thus manipulate the OPF computation in order to potentially increase their resulting profit. We consider two central payoff mechanisms and compare their vulnerability for such manipulations and analyze their effect on the total social cost.
\end{abstract}

Keywords: networks, manipulability, power transmission, optimal power flow

JEL classification: C71, L14, L94 


\title{
Hazug villamosenergia-termelők: a centralizált kifizetési mechanizmusok manipulálhatósága az áramkereskedelemben
}

\author{
Csercsik Dávid
}

\section{Összefoglaló}

Az optimális teljesítményáramok (OTÁ) problémája azon kérdéssel foglalkozik, hogyan lehet egy villamosenergia-átviteli hálózatot a leggazdaságosabban múködtetni. OTÁ problémák esetén a cél annak meghatározása, hogy a villamosenergia-termelés milyen értékeivel tudjuk kielégíteni a fogyasztók igényeit oly módon, hogy ne terheljük túl az átviteli hálózatot, valamint minimalizáljuk a termelési költségeket és az átviteli veszteségeket. A tanulmányban a hálózatot egyszerű DC load flow modellel írjuk le, valamint minden termelő esetében lineárisan csökkenő marginális termelési költséget tételezünk fel. Egy olyan piacot veszünk figyelembe, ahol az OTÁ meghatározása központi hatóság feladata, ami ismeri a hálózati és termelési paramétereket. Továbbá feltételezzük, hogy a villamosenergia-termelők kifizetése is központi mechanizmus alapján történik. Azt a lehetőséget vizsgáljuk, hogy mi történik, ha a termelők nem valós adatokat adnak meg, így manipulálva az OPF-számítást és potenciálisan növelve profitjukat. Két különböző központi kifizetési mechanizmust vizsgálunk és összehasonlítjuk manipulálhatóságukat.

Tárgyszavak: hálózatok, villamosenergia-átvitel, manipulálhatóság, optimális teljesítményáramok

JEL kód: C71, L14, L94 


\title{
Lying generators: Manipulability of centralized payoff mechanisms in electrical energy trade
}

\author{
Dávid Csercsik *†
}

January 27, 2015

\begin{abstract}
Optimal power flow (OPF) problems are focussing on the question how a power transmission network can be operated in the most economic way. The general aim in such scenarios is to optimize generator scheduling in order to meet consumption requirements, transmission constraints and to minimize the overall generation cost and transmission losses. We use a simple lossless DC load flow model for the description of the transmission network, and assume linearly decreasing marginal cost of generators with different parameters for each generator. We consider a scenario in which the generation values regarding the OPF are calculated by a central authority who is aware of the network parameters and production characteristics. Furthermore, we assume that a central mechanism is applied for the determination of generator payoffs in order to cover their generation costs and assign them with some profit. We analyze the situation when generators may provide false information about their production parameters and thus manipulate the OPF computation in order to potentially increase their resulting profit. We consider two central payoff mechanisms and compare their vulnerability for such manipulations and analyze their effect on the total social cost.
\end{abstract}

Keywords: Networks, manipulability, power transmission, optimal power

\footnotetext{
* Game Theory Research Group, Centre for Economic and Regional Studies of the Hungarian Academy of Sciences, Budaörsi 45., H-1112 Budapest. Email: csercsik@itk.ppke.hu.

†Pázmány Péter Catholic University, Práter U. 50/A 1083 Budapest
} 


\section{flow}

JEL-codes: C71, L14, L94

\section{Introduction}

Because of its extreme importance, power system economics (Kirschen and Strbac, 2004) has been an intensively researched interdisciplinary area. The trends of electricity market liberalization, together with occasionally rapidly extending consumption in long term and consumption peaks in short term, put increasing load on system operators and authorities responsible for network operation and expansion.

If one wishes to analyze the electrical energy market as interactions of market participants, he has to take into account that the possible interactions are constrained by laws of physics as well as by market regulations.

Optimal power flow (OPF) problems (Dommel and Tinney, 1968; Conejo and Aguado, 1998) dominantly aim to optimize the system operation costs, namely minimize instantaneous generating costs and/or transmission losses under various assumptions, however the objective function may be based on voltage profile or voltage stability considerations as well (Abido, 2002). The control variables of such problems in addition to generator production rates may include the voltage angles of the buses (Conejo and Aguado, 1998), transformation ratios, states of flexible ac transmission systems (FACTS) (Hingorani, 1993; Hingorani, Gyugyi, and El-Hawary, 2000; Song and Johns, 1999) which affect the transmission performance of power lines, and switching variables which alter the topology of the transmission network (Fisher, O'Neill, and Ferris, 2008; Hedman, O'Neill, Fisher, and Oren, 2008; O’Neill, Hedman, Krall, Papavasiliou, and Oren, 2010). These optimal transmission switching models, which formulate the optimization as a mixed integer problem, usually assume $n-1$ contingency reliability (Hedman, O’Neill, Fisher, and Oren, 2009) (in general, $n$ is the number of system components), which means that the effects of single line and generator failures on the network are included in the analysis. The latest models of Hedman, Ferris, O'Neill, Fisher, and Oren (2010) even include generator startup and shutdown costs as well.

For the optimization problems resulting from different OPF scenarios, numerous solution approaches have been proposed including e.g. the Newton-approach (Sun, Ashley, 
Brewer, Hughes, and Tinney, 1984), particle swarm optimization (Abido, 2002), as well as evolutionary and genetic algorithms (Yuryevich and Wong, 1999; Bakirtzis, Biskas, Zoumas, and Petridis, 2002). For surveys see (Momoh, Adapa, and El-Hawary, 1999; Momoh, El-Hawary, and Adapa, 1999; Huneault and Galiana, 1991).

Our aim in this paper however is not to provide novel or more efficient methods for OPF calculation, but to analyze the economic aspects of a regulated electricity market model, with a fixed network topology, where the OPF calculation is carried out by a central authority, which is considered to be independent of the generators. We will assume that generators are obligated to provide information about their own production characteristics to this central authority (independent network operator or INO in the following), and investigate how possibly provided unrealistic information affects the resulting profits under various assumptions. A further aim is to determine the effect of cooperation, which is interpreted in this case as coordinated provision of (potentially false) information for the INO. We assume a simple lossless DC load flow model, and linearly decreasing marginal generation costs.

\section{Materials and Methods}

First, let us review the DC load flow model used for the description of the power transmission network.

The DC load flow model has been widely used among papers analyzing power system economics (see e.g. Tseng, Oren, Cheng, Li, Svoboda, and Johnson (1999); Yao, Oren, and Adler (2004); Sauma and Oren (2007)). For the sake of simplicity we will assume that every node of the energy transmission network is assigned to a certain generator or consumer. The most straightforward interpretation of the model is that we study the high voltage networks, in which case consumers correspond to local energy providers who own mid-voltage networks.

We assume that the power transmission system is described by a graph, the system graph, in which $n$ nodes (or buses) are connected by $m$ edges, which naturally represent the transmission lines. We assume $n_{g}$ generators, and $n_{c}=n-n_{g}$ consumers.

The details of the DC load flow model are described in Appendix A. The notations and the mathematical formalism are based on Oren, Spiller, Varaiya, and Wu (1995) and Contreras (1997). One of the most important properties of the DC load flow model is that 
given a power injection vector $P$, the network topology and line parameters, the flows $\left(q_{i j}\right)$ can be uniquely determined via linear equations. We assume that the first $n_{g}$ elements of $P$ correspond to generators for which the $p_{i}$ values are negative. $P_{g}$ will denote the truncated vector, which holds only the first $n_{g}$ elements of $P$. During the optimization process, these elements of $P$ will represent the decision variables, while the remaining elements corresponding to the consumption values will be constant. $P_{c}$ will denote the remaining part of $P$ corresponding to consumers.

In the following we itemize some additional assumptions regarding our model

- We neglect the demand elasticity of consumers.

- Each generator has a limited production capacity.

- The concept of plant utilization is important when analysing the costs of generating electricity. It can be observed that a plant with low utilization inevitably has a high unit cost of production because the same investment and fixed costs of operation and maintenance are recovered over fewer units of production. As the most simple approach, we assume that generation cost per unit is linear decreasing function of generated quantity ${ }^{1}: c_{j}\left(p_{j}\right)=a_{j}-m_{j} p_{j}$ where $a_{j}[\$ / \mathrm{MWh}]$ and $m_{j}>0\left[\$ / \mathrm{MWh}^{2}\right]$ are the constants describing the production characteristics of generator $j$ (which depend on the applied technology), while $p_{j}[\mathrm{MWh}]$ is the total power produced by the generator $j$. The total generation cost of a generator can be formulated as: $C_{j}=c_{j}\left(p_{j}\right) p_{j}$. The vector $C$ holds the generation costs.

- The income $\left(I_{j}\right)$, and so the profit $\left(\gamma_{j}\right)$, of a certain generator $j$ depends on the actual market regulation mechanism, in other words on the applied payoff mechanism (see later).

\subsection{Calculating the optimal power flow}

Let us assume that the fixed consumption needs of nodes $n_{g}+1, \ldots, n_{g}+n_{c}$ are denoted by $p_{i}^{n}\left(i \in\left\{1, . ., n_{c}\right\}\right)$. In our case the optimal power flow is the solution of the following

\footnotetext{
${ }^{1}$ Although it is possible that near the production capacity limits the validity of the decreasing marginal cost assumption is questionable, to keep the model as simple as possible, we restrict our analysis to the case where the linearly decreasing marginal cost assumption is valid. The model can be easily extended with more complex production characteristics.
} 
problem.

$$
\min _{P_{g}} \sum_{j=1}^{n_{g}} C_{j}\left(p_{j}\right)
$$

subject to the constraints

$$
\begin{aligned}
& \left|B^{D} A^{T} B^{+} P\right|<\bar{Q} \\
& -I_{n_{g}} P_{g} \leq \bar{P}_{g} \\
& \sum_{i=1}^{n} p_{i}=0 \\
& I_{n_{c}} P_{c}=P_{n}
\end{aligned}
$$

where $C_{j}\left(p_{j}\right)=c_{j}\left(p_{j}\right) p_{j}$ is the generation cost of generator $j$. Eq. 2 corresponds to the prevention of line flow overloads, eq. 3 describes the limited generation capacity of generators where the vector $\bar{P}_{g}$ length $n_{g}$ holds the maximal generation values $\left(I_{n_{g}}\right.$ is the unitary matrix of size $n_{g}$ - remember that the $P$ values for generators are negative), while eqs. 4 and 5 refer to the power balance for the whole network and the fulfillment of consumption needs respectively (the vector $P_{n}$ of length $n_{c}$ is composed of the $p_{i}^{n}$ values). We will denote the optimal power injection vector, the solution of 1 with $P^{o p t}$.

This is a smooth nonlinear optimization problem with equality and inequality type constraints. The absolute value from the constraint 2 may be removed as described in $\left(\right.$ Kaltenbach and Hajdu, 1971) ${ }^{2}$. In Appendix B several available optimization methods have been compared for the OPF calculation. Based on the results, we will use the the SCIP algorithm (Achterberg, 2009) for OPF calculation for the rest of the paper, as it turned out to be the most efficient.

\subsection{The example network}

As it can be seen in Fig. 1, the generator capacities are $\bar{P}_{g}=[4,5,4,6]^{T}$ while the consumption demands are defined as $P_{n}=\left[\begin{array}{lll}3 & 1 & 1\end{array}\right]^{T} \cdot \bar{q}_{s t}$ can be calculated as $1.3 Y_{s t}$. The

\footnotetext{
${ }^{2}$ This approach doubles the number of variables in the optimization problem (since it separates the positive and negative part of the variables).
} 


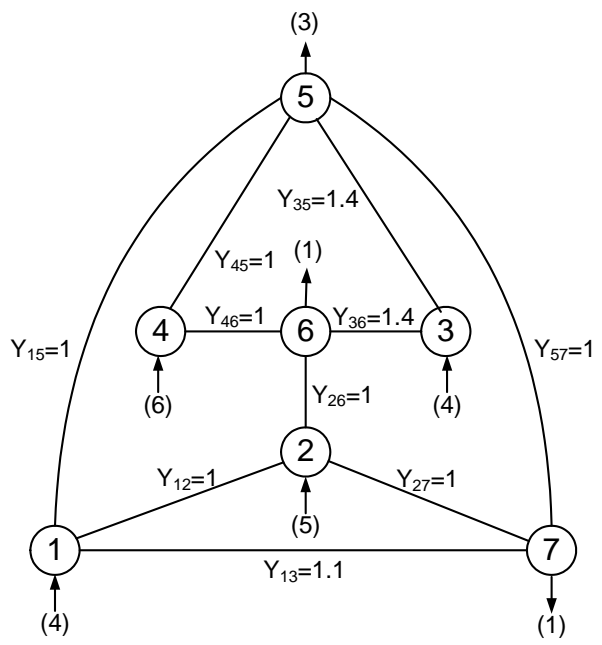

Figure 1: Topology and parameters of the example network. The $Y_{s t}$ values denote the admittance values of the line connecting node $s$ and $t$. The numbers next to the nodes indicate the available generation amounts and required consumption quantities denoted by arrows pointing from the number to the node and vice versa respectively.

\begin{tabular}{|c|c|c|c|c|c|c|c|}
\hline$a_{1}$ & $a_{2}$ & $a_{3}$ & $a_{4}$ & $m_{1}$ & $m_{2}$ & $m_{3}$ & $m_{4}$ \\
\hline 0.65 & 0.63 & 0.68 & 0.7 & 0.1 & 0.07 & 0.0 & 0.04 \\
\hline
\end{tabular}

Table 1: Production parameters of the example network. Dimensions: $a_{i}[\$ / \mathrm{MWh}], m_{i}$ $\left[\$ / \mathrm{MWh}^{2}\right]$.

above parameters and the network structure was determined in order to provide a computationally tractable example, where a significant number of consumer-generator matchings is feasible. The multiplier 1.3 was determined in order to imply real transmission constraints on the set of possible matchings under the assumed $\bar{P}_{g}$ and $P_{c}$ values.

The production parameters are summarized in Table 1.

The production curves are depicted in Fig. 2.

\subsection{Payoff mechanisms}

We assume that after each generator reports its production parameters, the INO determines the OPF. Thereafter the payoff of generators is calculated based on their actual production values corresponding to the OPF. The following payoff mechanisms are considered 


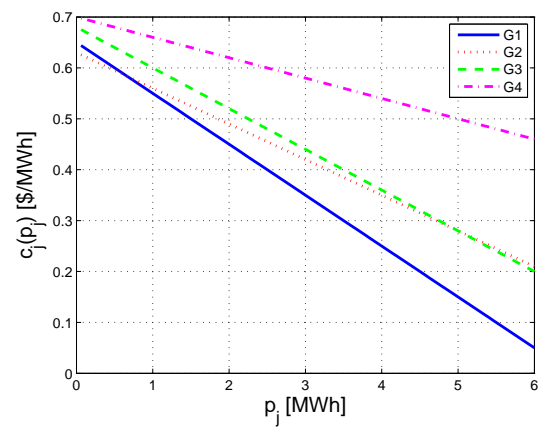

Figure 2: Linearly decreasing marginal cost production characteristics of the various generators.

1. Unitary price - In this case, independently of the production cost, generators are rewarded based on the produced quantity. We assume that the unitary payoff $\left(i_{u}\right)$ is always high enough to cover the production costs of generators. In this case the income of generator $j$ may be formalized as

$$
I_{j}=i_{u} p_{j}
$$

2. Proportional profit - As an alternative we may assume a payoff mechanism which distinguishes between generators using different technology, and compensates higher production costs more. This mechanism may be regarded as the most simple one which determines the payoff according to the possibly different production characteristics. In this setup each generator receives an amount, which ensures a payoff proportional to its total generation cost. We denote the profit ratio by $r_{P}$. In this case the income of generator $j$ can be calculated as

$$
I_{j}=\left(1+r_{P}\right) C_{j}^{c a l c}
$$

where $C_{j}^{\text {calc }}$ is the cost of generation regarding generator $j$, calculated by the INO from the reported production parameters.

In both cases the profit is calculated as the difference of the income and the real generation cost $\gamma_{j}=I_{j}-C_{j}$. The vectors $I$ and $\gamma$ are composed of $I_{j}$ and $\gamma_{j}$ values. 
Let us note that the social cost (the amount that the INO pays to the generators) is always the same in the first case but may depend on reported values in the second case.

More precisely, in the case of the proportional profit mechanism, both the increase and decrease of the TSC (total social cost) is possible. See Example 1 later for details.

If the reference profit of the lying generator is zero (it does not generate any power), it may report more effective production characteristics to modify the OPF to a state where his generation value is positive, with a positive profit (which is in this case less then the reference profit determined by the proportional profit principle).

\subsection{The optimization problem of the lying generators}

While the INO schedules the generators in order to reach the lowest overall production cost taking into account the reported characteristics, generators may lie about their production parameters to modify/maximize their payoff. As a simplest case we will assume that only one generator (generator 1) is lying and take a close look to the implied optimization problem.

\section{Example 1}

We compare 4 cases. Case 1 serves as reference.

1. In the reference case, when all generators report their real production parameters, the power injection vector corresponding to the OPF, the calculated $\left(C^{\text {calc }}\right)$ and real $(C)$ generation costs are

$$
P^{o p t}=\left(\begin{array}{c}
-3.0006 \\
0 \\
-1.9994 \\
0 \\
3 \\
1 \\
1
\end{array}\right) \quad C^{c a l c}=\left(\begin{array}{c}
1.05 \\
0 \\
1.0398 \\
0
\end{array}\right) \quad C=\left(\begin{array}{c}
1.05 \\
0 \\
1.0398 \\
0
\end{array}\right)
$$

while, incomes and profits according to the unitary price mechanism $\left(I^{1} / \gamma^{2}\right)$ and to 
the proportional profit mechanism $\left(I^{2} / \gamma^{2}\right)$ are

$$
I^{1}=\left(\begin{array}{c}
2.1004 \\
0 \\
1.3996 \\
0
\end{array}\right) \quad I^{2}=\left(\begin{array}{c}
1.7851 \\
0 \\
1.7676 \\
0
\end{array}\right) \quad \gamma^{1}=\left(\begin{array}{c}
1.0504 \\
0 \\
0.3598 \\
0
\end{array}\right) \quad \gamma^{2}=\left(\begin{array}{c}
0.7350 \\
0 \\
0.7278 \\
0
\end{array}\right)
$$

2. If generator one reports the production parameters $a^{1}=0.65 \mathrm{~m}^{1}=0.08877$ instead of his real values, the power injection vector corresponding to the OPF, the calculated $\left(C^{c a l c}\right)$ and real $(C)$ generation costs are

$$
P^{\text {opt }}=\left(\begin{array}{c}
-3.0006 \\
0 \\
-1.9994 \\
0 \\
3 \\
1 \\
1
\end{array}\right) \quad C^{\text {calc }}=\left(\begin{array}{c}
1.1511 \\
0 \\
1.0398 \\
0
\end{array}\right) \quad C=\left(\begin{array}{c}
1.05 \\
0 \\
1.0398 \\
0
\end{array}\right)
$$

incomes and profits according to the unitary price mechanism $\left(I^{1} / \gamma^{2}\right)$ and to the proportional profit mechanism $\left(I^{2} / \gamma^{2}\right)$ in thi case are

$$
I^{1}=\left(\begin{array}{c}
2.1004 \\
0 \\
1.3996 \\
0
\end{array}\right) \quad I^{2}=\left(\begin{array}{c}
1.9569 \\
0 \\
1.7676 \\
0
\end{array}\right) \quad \gamma^{1}=\left(\begin{array}{c}
1.0504 \\
0 \\
0.3598 \\
0
\end{array}\right) \quad \gamma^{2}=\left(\begin{array}{c}
0.9069 \\
0 \\
0.7278 \\
0
\end{array}\right)
$$

One would expect that if a "lying" generator reports higher generation costs, it will be scheduled for a smaller power. However, as this case demonstrates, if the proportional profit mechanism is applied, the $P^{o p t}$ vector does not change, and so neither does $I^{1}$ or $\gamma^{1}$. On the other hand $I^{2}$ and $\gamma^{2}$ are increased. In other words using generator 1 for generation is still cheaper than changing to an other generating unit.

This case shows as well that in the case of the proportional profit mechanism, when the reference profit of the lying generator is nonzero, it is possible that it may increase its reported generation cost and thus increase the TSC (which may be calculated as the sum of the elements of $I^{2}$ ). 
3. Next we analyze what happens when generator 1 further decreases the reported value of of $m^{1}$ to $m^{1}=0.08876$. In this case the power injection vector corresponding to the OPF, the calculated $\left(C^{c a l c}\right)$ and real $(C)$ generation costs are

$$
P^{\text {opt }}=\left(\begin{array}{c}
0 \\
-3.4885 \\
-1.5115 \\
0 \\
3 \\
1 \\
1
\end{array}\right) \quad C^{\text {calc }}=\left(\begin{array}{c}
0 \\
1.3459 \\
0.8450 \\
0
\end{array}\right) \quad C=\left(\begin{array}{c}
0 \\
1.3459 \\
0.8450 \\
0
\end{array}\right)
$$

incomes and profits according to the unitary price mechanism $\left(I^{1} / \gamma^{2}\right)$ and to the proportional profit mechanism $\left(I^{2} / \gamma^{2}\right)$ in thi case are

$$
I^{1}=\left(\begin{array}{c}
0 \\
2.4420 \\
1.0580 \\
0
\end{array}\right) \quad I^{2}=\left(\begin{array}{c}
0 \\
2.2880 \\
1.4366 \\
0
\end{array}\right) \quad \gamma^{1}=\left(\begin{array}{c}
0 \\
1.0961 \\
0.2130 \\
0
\end{array}\right) \quad \gamma^{2}=\left(\begin{array}{c}
0 \\
0.9421 \\
0.5915 \\
0
\end{array}\right)
$$

At this point, the calculated cost of the other power injection configuration $\left(P^{o p t}\right)$, where the system no longer uses generator 1 becomes lower than using generator 1 , and the operation abruptly changes to a different operating point. Generator 1 can not lie arbitrary big to increase its profit.

4. Let us examine what happens when generator 2 reports $a_{2}=0.59$ (while the real value of the parameter is 0.63 ). In this case

$$
P^{o p t}=\left(\begin{array}{c}
0 \\
-3.4885 \\
-1.5115 \\
0 \\
3 \\
1 \\
1
\end{array}\right) \quad C^{c a l c}=\left(\begin{array}{c}
0 \\
1.2063 \\
0.8450 \\
0
\end{array}\right) \quad C=\left(\begin{array}{c}
0 \\
1.3459 \\
0.8450 \\
0
\end{array}\right)
$$


while, incomes and profits according to the unitary price mechanism $\left(I^{1} / \gamma^{2}\right)$ and to the proportional profit mechanism $\left(I^{2} / \gamma^{2}\right)$ are

$$
I^{1}=\left(\begin{array}{c}
0 \\
2.4420 \\
1.0580 \\
0
\end{array}\right) \quad I^{2}=\left(\begin{array}{c}
0 \\
2.0508 \\
1.4366 \\
0
\end{array}\right) \quad \gamma^{1}=\left(\begin{array}{c}
0 \\
1.0961 \\
0.2130 \\
0
\end{array}\right) \quad \gamma^{2}=\left(\begin{array}{c}
0 \\
0.7049 \\
0.5915 \\
0
\end{array}\right)
$$

This example demonstrates that, if assuming the proportional payoff mechanism, generator 2 was able to change the operation point to a state where its generation is greater than zero and thus increase its profit from zero to 0.7049 , while the TSC has been decreased from 3.5527 to 3.4874 .

The above simple example shows that the objective function of the generators optimization problem is non-continuous (the implied profit may change abruptly). To study which nonlinear solver suits the best to this type of problem, a series of simulation studies were performed.

\subsection{Optimization methods for the lying generators}

In this subsection we use the same randomization of the network and production characteristics during the simulations like in Appendix A, and compare the efficiency of various optimization algorithms regarding lying. We assume that only player one is lying. Furthermore, we assumed that the lying of the generators is credible only if the reported values stay in $\pm 20 \%$ interval of the real values.

The set of the compared algorithms is slightly different. The computations were carried out in MATLAB. Regarding the SCIP algorithm used in the OPF calculation, SCIP only supports a subset of MATLAB commands, and the objective function to be minimized includes an OPF calculation (in other words an 'inner' optimization process is required to determine the value of the objective function), this method can not be used in this case. The IPOPT and L-BFGS-B methods used for the comparison of solvers for the OPF calculation are designed for continuous, differentiable objective functions, and since in this case the objective function is discontinuous, they have to be discarded. The solver NLOPT ran into numerical problems from time to time. The reason for this probably lies in the non-continuous nature of the optimization problem. 
On the other hand three algorithms were added to the test set, which were unable to handle the optimal flow problem because of the nature of constraints, but here they proved to be useful.

- Particle swarm (PS) pattern search method (Vaz and Vicente, 2007).

- Simulated annealing (SA) (van Laarhoven and Aarts, 2008) (SA), as implemented in the MATLAB function simulannealbnd

- Nomad (Le Digabel, 2011).

100 repeated runs were completed with each algorithm and each payoff mechanism. Table 2 holds the accumulated surplus value regarding each algorithm compared to the reference case (real parameters reported). Regarding the unitary price payoff mechanism the unitary price was set to 0.7 to ensure positive profit for each generator. In the proportional profit payoff mechanism, the value $r_{P}=0.1$ was used for profit ratio.

\begin{tabular}{|c|c|c|c|c|c|}
\hline Payoff mech. & FILTER & NOMAD & PSWARM & GA & SA \\
\hline 1 & 0 & 0.14 & 0.27 & 0.26 & 0.28 \\
2 & 0.23 & 0.24 & 0.25 & 0.24 & 0.25 \\
\hline
\end{tabular}

Table 2: The result of optimization regarding lying in the case of various optimization methods and payoff mechanisms: Increase of the resulting profit due to lying. Player 1 is lying. Averaged results of 100 simulations.

The comparison of the resulting profit makes sense regarding a given payoff mechanism only, since the base profits are different when considering different payoff mechanisms. In the case of unitary pricing (1), only the NOMAD, PSWARM, SA and GA algorithms were able to improve the profit in 19, 39, 39 and $42 \%$ of the cases respectively, while in the case of the proportional profit payoff mechanism, the optimization methods brought improvement compared to the reference non-lying case in $75,77,78,75$ and $79 \%$ of the cases respectively. In the case of unitary pricing, the FILTER algorithm was not able to improve the results (lying based on this optimization method did not bring any significant benefit to the lying generator). This example points toward the hypothesis that the proportional profit mechanism is more easy to manipulate, and the simulated annealing mechanism is the most efficient in both cases. Regarding both cases of payoff mechanism, 
simulated annealing (SA) (van Laarhoven and Aarts, 2008) provided the best results for the analyzed optimization problem, and so in the rest of the paper we will use this method for the determination of the reported production values of generators when lying.

It is straightforward to do the analysis in the cases when not player one, but one of the other players is lying to see how the results depend on production characteristics and position in the network. If only player 2 is lying (determining the reported values with SA), the lying helps him to improve his profit in 46 and $79 \%$ considering unitary pricing and proportional profit payoff mechanisms respectively. The values are 46 and $79 \%$ respectively considering player 3 , and 42 and 62 in the case of player 4 .

Regarding the effect of the proportional profit payoff mechanism on the TSC, the sign of the change in the TSC due to lying strongly depends on the real production characteristics of the player. If a generator has an efficient production capability, it will be chosen with greater chance for production, even if the real values are reported. In this case, as discussed in 2.3 the TSC will increase. Simulation results show that in the case of player one lying, the TSC increased in $60 \%$ of the cases while decreased in $24 \%$ (in the rest of the cases it did not practically change). In the case of player 2 these values are $46 \%$ and $26 \%$. Regarding player 3 we get $58 \%$ and $32 \%$, while in the case of player 4 the vales are $42 \%$ and $22 \%$ respectively. The results are in good agreement of what we expect from the production characteristics and the hypothesis detailed in section 2.3. As Fig. 2 shows, player 1 has the most efficient production characteristics. This implies that he is often included in the basic (not lying) OPF setup. In these cases his base production is greater than zero, and with false reports he may keep his production demand, while increasing his profit and the TSC as well. In contrast, in the player 4 with the less efficient production curve has this opportunity in much smaller percent of the cases.

\section{Conclusions}

Based on a conventional DC load flow model we analyzed a simple model of a centrally regulated electrical power market. In the proposed model the INO calculates the optimal power flow and determines the generation values according to the production characteristics reported by the generators. The generators are paid according to two different payoff mechanisms - the unitary price and the proportional profit mechanism. We assumed that generators may report false values to manipulate the INOs decision and thus increase their 
profit. While the profit mechanism can be considered more fair, since it takes into account the different production characteristics while determining the payoffs, simulations shown that this mechanism is more easy to manipulate by the proposed lying actions. Regarding the analyzed example, the proportional profit mechanism indicated a significant potential to increase the TSC when a lying generator is present. In addition the efficiency of different numerical optimization algorithms were compared both for the OPF and the lying problem.

\section{Acknowledgements}

This work was supported by the Hungarian National Fund (OTKA NF-104706) and by the Hungarian Academy of Sciences under its Momentum Programme (LP-004/2010) and by grant KAP-1.2-14/001 of the Pázmány Péter Catholic University. The author thanks Gábor Szederkényi for the helpful discussions on optimization issues.

\section{Appendix A: DC Load flow model}

In the proposed model generators can be characterized by the quantity of actual and maximal generated (or supplied) power, while consumers are described by their power consumption (constant for each consumer node). We assume that a transmission line is characterized by its admittance value, denoted by $Y_{i j}$ (which will be equal to susceptance in this case, for we neglect the real part of impedance values), and maximum transmission capacity (or branch power flow limit) $\bar{q}_{i j}$.

According to our modelling considerations, we describe the voltage at node $i$ with sinusoidal waveform:

$$
v_{i}(t)=V_{i} \sin \left(\omega t+\theta_{i}\right)
$$

where $V_{i}$ stands for the magnitude, $\omega=2 \pi f$ denotes the frequency in $\mathrm{rad} / \mathrm{s}$ and $\theta_{i}$ is the phase angle.

If we assume that the nodes $i$ and $j$ are connected by a transmission line with admittance $Y_{i j}=Y_{j i}$, the (real) power flow from $i$ to $j$ can be described with:

$$
q_{i j}=V_{i} V_{j} Y_{i j} \sin \left(\theta_{i}-\theta_{j}\right)
$$

By definition $q_{i j}>0$ if the power flows from $i$ to $j$. This implies $q_{i j}=-q_{j i}$ for flows of opposite direction. We can formalize the energy conservation for each node as follows. The 
net power $p_{i}$ injected into (or drawn from) the network at bus $i$ addition to the total inflow is equal to the total outflow:

$$
p_{i}=\sum_{j=1}^{n} q_{i j}
$$

Without the loss of generality, let us assume $V_{i} \equiv 1$. In this case

$$
p_{i}=\sum_{j=1}^{n} Y_{i j} \sin \left(\theta_{i}-\theta_{j}\right)
$$

which means $n-1$ independent equations (as $p_{1}+\ldots+p_{n}=0$ ). Let us choose $\theta_{n} \doteq 0$. In this case the individual line flows can be expressed as:

$$
q_{i j}=Y_{i j} \sin \left(\theta_{i}-\theta_{j}\right)
$$

Assuming that $\left(\theta_{i}-\theta_{j}\right)$ is small, $\sin (x)$ may be approximated with $x$. This leads to the so called "DC load flow model", which exhibits the following uniqueness property: Given power injections and power consumptions at each node, the phase angles $\theta_{i}$ are determined by solving a system of linear equations. From the phase angle differences, the line flows can be uniquely determined.

We can summarize the equations in the following matrix formalism (Contreras, 1997):

The relation between the total inlet/outlet power and power flows can be described by

$$
A Q=P
$$

where $A \in \mathbb{R}^{n \times m}$ is the Node-branch incidence matrix of the network, $Q \in \mathbb{R}^{m}$ denotes the power flow vector, and $P \in \mathbb{R}^{n}$ is the power injection vector (composed of $\left[p_{1}, p_{2}, \ldots, p_{n}\right]$ ).

If we substitute the individual power flows in Equation 11 with the linearized expressions from Equation 7, we can write

$$
B(Y) \Theta=P
$$

where $B(Y) \in \mathbb{R}^{n \times n}$ denotes the susceptance matrix whose elements are $B_{k l}=-Y_{k l}$ for the off-diagonal terms and

$$
B_{k k}=\sum_{k \neq l} B_{k l}
$$

(the column sum of off-diagonals) for diagonal elements. $\Theta \in \mathbb{R}^{n}$ is vector of nodal voltage angles. 
The constraint describing the maximum line power flows can be derived as

$$
|Q|=\left|B^{D} A^{T} \Theta\right|<\bar{Q}
$$

where $|\bar{Q}|$ is branch power flow limit vector (composed of the elements $\bar{q}_{i j}$ ), and $B^{D}$ is a diagonal matrix with $B_{k k}^{D}=Y_{i j}$.

As we know from Equation $12, B \Theta=P$. The matrix $B$ is singular due to the column conservation property, but since in the calculation of flows only the differences of the elements of the vector $\Theta$ are appearing (see Equation 7), we may express it as

$$
\Theta=B^{+} P
$$

where $B^{+}$is the Moore-Penrose pseudoinverse of $B$. Constraint 13 becomes

$$
\left|B^{D} A^{T} \Theta\right|=\left|B^{D} A^{T} B^{+} P\right|<\bar{Q}
$$

\section{Appendix B: Optimization methods for the OPF}

As a preliminary study we compared the currently freely available optimization tools in MATLAB in the context of solving 1-5. The basic model was the topology of Network 1 as depicted in Fig 1, however the admittance values, and production characteristics were randomized around the nominal values described in section 2.2 as follows. $\tilde{Y}_{i j}=Y_{i j}+\Delta Y$ where $\Delta Y \in(-0.5,0.5), \tilde{a}^{j}=a^{j}+\Delta a$ where $\Delta a \in(-0.25,0.25)$, and $\tilde{m}^{j}=m^{j}+\Delta m$ where $\Delta m \in(-0.03,0.03)$ (each $\Delta$ value from uniform distribution).

The following algorithms were compared:

- Interior point optimizer (IPOPT), see (Wächter and Biegler, 2006)

- Filter-SQP Algorithm (Fletcher, Leyffer, and Toint, 2002)

- L-BFGS-B or Algorithm 778 (Zhu, Byrd, Lu, and Nocedal, 1997)

- NLOPT (Johnson, 2010)

- SCIP (Achterberg, 2009)

- The standard genetic algorithm (GA) of MATLAB (Goldberg and Holland, 1988) 
1000 repeated runs were completed with the randomized parameters for each algorithm $\mathcal{A}$. The evaluation was carried out as follows. For each run, the reference value of the objective function $F$ (the value of 1 ) at run $i$ denoted by $F_{\text {ref }}(i)$ was defined as the lowest value found by the various algorithms in the current run $\left.F_{r e f}(i)=\min _{\mathcal{A}} F_{\mathcal{A}}(i)\right)$. The error of the algorithm $\mathcal{A}$ at $\operatorname{run} i\left(\Upsilon_{\mathcal{A}}(i)\right)$ then is defined as

$$
\Upsilon_{\mathcal{A}}(i)=F_{\mathcal{A}}(i)-F_{\text {ref }}(i)
$$

The resulting error is the sum over the repetitive runs $\Upsilon_{\mathcal{A}}=\sum_{i} \Upsilon_{\mathcal{A}}(i)$. The resulting values are as follows.

\begin{tabular}{|c|c|c|c|c|c|c|}
\hline Payoff mech. & IPOPT & FILTER & L-BFGS-B & NLOPT & SCIP & GA \\
\hline$\Upsilon$ & 74.6 & 122.3 & 74.6 & 1044.1 & 2 & 882 \\
\hline
\end{tabular}

Table 3: Comparison of various optimization methods regarding optimal power flow computation .

As it can be seen from the results summarized in 3, the SCIP algorithm finds the best value of the objective function in almost every case, and it is undoubtedly the most well suited for this optimization problem.

\section{References}

ABIDO, M. (2002): "Optimal power flow using particle swarm optimization," International Journal of Electrical Power \& Energy Systems, 24(7), 563-571.

ACHTERBerG, T. (2009): "SCIP: solving constraint integer programs," Mathematical Programming Computation, 1(1), 1-41.

Bakirtzis, A. G., P. N. Biskas, C. E. Zoumas, and V. Petridis (2002): "Optimal power flow by enhanced genetic algorithm," Power Systems, IEEE Transactions on, $17(2), 229-236$.

Conejo, A. J., And J. A. Aguado (1998): "Multi-area coordinated decentralized DC optimal power flow," Power Systems, IEEE Transactions on, 13(4), 1272-1278. 
Contreras, J. (1997): "A Cooperative Game Theory Approach to Transmission Planning in Power Systems," Ph.D. thesis, University of California, Berkeley.

Dommel, H. W., And W. F. Tinney (1968): "Optimal power flow solutions," power apparatus and systems, IEEE transactions on, 10, 1866-1876.

Fisher, E. B., R. P. O'Neill, And M. C. Ferris (2008): "Optimal transmission switching," Power Systems, IEEE Transactions on, 23(3), 1346-1355.

Fletcher, R., S. Leyffer, and P. L. Toint (2002): "On the Global Convergence of a Filter-SQP Algorithm," SIAM Journal on Optimization, 13(1), 44-59.

GoldberG, D. E., And J. H. Holland (1988): "Genetic algorithms and machine learning," Machine learning, 3(2), 95-99.

Hedman, K. W., M. C. Ferris, R. P. O’Neill, E. B. Fisher, and S. S. Oren (2010): "Co-optimization of generation unit commitment and transmission switching with N-1 reliability," Power Systems, IEEE Transactions on, 25(2), 1052-1063.

Hedman, K. W., R. P. O’Neill, E. B. Fisher, and S. S. Oren (2008): "Optimal transmission switching-sensitivity analysis and extensions," Power Systems, IEEE Transactions on, 23(3), 1469-1479.

Hedman, K. W., R. P. O’Neill, E. B. Fisher, and S. S. Oren (2009): "Optimal transmission switching with contingency analysis," Power Systems, IEEE Transactions on, 24(3), 1577-1586.

Hingorani, N. G. (1993): "Flexible AC transmission," spectrum, IEEE, 30(4), 40-45.

Hingorani, N. G., L. Gyugyi, And M. El-Hawary (2000): Understanding FACTS: concepts and technology of flexible AC transmission systems, vol. 1. IEEE press New York.

Huneault, M., And F. Galiana (1991): "A survey of the optimal power flow literature," Power Systems, IEEE Transactions on, 6(2), 762-770.

Johnson, S. G. (2010): "The NLopt nonlinear-optimization package," . 
Kaltenbach, J., and L. Hajdu (1971): "Optimal Ccorrective Rescheduling For Power System Security," IEEE Transactions on power Apparatus and Systems, 90, 843-851.

Kirschen, D., and G. Strbac (2004): Fundamentals of Power System Economics. John Wiley \& Sons, Ltd, Chichester, UK.

Le Digabel, S. (2011): "Algorithm 909: NOMAD: Nonlinear optimization with the MADS algorithm," ACM Transactions on Mathematical Software (TOMS), 37(4), 44.

Momoh, J. A., R. Adapa, And M. El-Hawary (1999): "A review of selected optimal power flow literature to 1993. I. Nonlinear and quadratic programming approaches," Power Systems, IEEE Transactions on, 14(1), 96-104.

Momoh, J. A., M. El-Hawary, and R. Adapa (1999): "A review of selected optimal power flow literature to 1993. II. Newton, linear programming and interior point methods," Power Systems, IEEE Transactions on, 14(1), 105-111.

O'Neill, R. P., K. W. Hedman, E. A. Krall, A. Papavasiliou, and S. S. Oren (2010): "Economic analysis of the N-1 reliable unit commitment and transmission switching problem using duality concepts," Energy Systems, 1(2), 165-195.

Oren, S., P. Spiller, P. Varaiya, and F. Wu (1995): "Folk Theorems on Transmission Access: Proofs and Counter Examples," Working papers series of the Program on Workable Energy Regulation (POWER) PWP-023, University of California Energy Institute 2539 Channing Way Berkeley, California 94720-5180, www.ucei.berkeley.edu/ucei.

Sauma, E. E., And S. S. Oren (2007): "Economic criteria for planning transmission investment in restructured electricity markets," Power Systems, IEEE Transactions on, 22(4), 1394-1405.

Song, Y. H., And A. T. Johns (1999): Flexible ac transmission systems (FACTS), vol. 30. IET.

Sun, D. I., B. Ashley, B. Brewer, A. Hughes, and W. F. Tinney (1984): "Optimal power flow by Newton approach," Power Apparatus and Systems, IEEE Transactions on, 10, 2864-2880. 
Tseng, C.-L., S. S. Oren, C. S. Cheng, C.-A. Li, A. J. Svoboda, and R. B. JohnSON (1999): "A transmission-constrained unit commitment method in power system scheduling," Decision Support Systems, 24(3), 297-310.

Van LaArhoven, P., And E. Aarts (2008): Simulated Annealing: Theory and Applications. Springer.

VAZ, A. I. F., AND L. N. ViCEnte (2007): "A particle swarm pattern search method for bound constrained global optimization," Journal of Global Optimization, 39(2), 197-219.

WÄchter, A., And L. T. Biegler (2006): "On the implementation of an interiorpoint filter line-search algorithm for large-scale nonlinear programming," Mathematical programming, 106(1), 25-57.

Yao, J., S. S. Oren, And I. Adler (2004): "Computing Cournot equilibria in two settlement electricity markets with transmission constraint," in System Sciences, 2004. Proceedings of the 37th Annual Hawaii International Conference on, pp. 9-pp. IEEE.

YuRYeViCH, J., AND K. P. WONG (1999): "Evolutionary programming based optimal power flow algorithm," Power Systems, IEEE Transactions on, 14(4), 1245-1250.

Zhu, C., R. H. Byrd, P. Lu, and J. Nocedal (1997): "Algorithm 778: L-BFGS-B: Fortran subroutines for large-scale bound-constrained optimization," ACM Transactions on Mathematical Software (TOMS), 23(4), 550-560. 